\title{
Fish diet from Manacapuru Big Lake complex (Amazon): a approach starting from the traditional knowledge
}

\author{
Sérgio Roberto Moraes Rebelo ${ }^{1,4}$, Carlos Edwar de Carvalho Freitas ${ }^{2}$ \& Maria Gercilia Mota Soares ${ }^{3}$ \\ ${ }^{1}$ Programa de Pós-graduação em Ciências do Ambiente e Sustentabilidade na Amazônia, \\ Universidade Federal do Amazonas - UFAM, Av. Gen. Otávio Ramos Jordão, 300, \\ CEP 69077-000, Manaus, AM, Brasil \\ ${ }^{2}$ Departamento de Ciências Pesqueiras, Faculdade de Ciências Agrárias, \\ Universidade Federal do Amazonas - UFAM, Av. Gen. Otávio Ramos Jordão, 300, \\ CEP 69077-000, Manaus, AM, Brasil \\ ${ }^{3}$ Instituto Nacional de Pesquisas da Amazônia - INPA, \\ CP 478, CEP 69011-090, Manaus, AM, Brasil \\ ${ }^{4}$ Corresponding author: Sérgio Roberto Moraes Rebelo, e-mail: srebelom@hotmail.com
}

REBELO, S.R.M., FREITAS, C.E.C. \& SOARES, M.G.M. Fish diet from Manacapuru Big Lake complex (Amazon): a approach starting from the traditional knowledge. Biota Neotrop. 10(3): http://www. biotaneotropica.org.br/v10n3/en/abstract?article+bn00810032010.

\begin{abstract}
In the Amazon fishing is one of the main economic activities and higher value to traditional riverine communities of the region. Considering this importance is to suppose that the riverine populations have knowledge about fish fauna explores for them, because their forming culture that maintain a strait relationship with natural resources. This study aim to elevate the traditional knowledge of the fishermen from the riverine communities in the Big Lake Complex about the fish alimentary diet caught for commercialization and consumption. This study was realized in the Manacapuru Big Lake Complex through interview jointed with 62 fishermen. The results presents a detailed knowledge about the tambaqui, tucunaré, pacu, acará-açú, curimatã, aruanã, matrinxã, piranha and pirapitinga fish feeding compatible with the laboratory analyzes and with the specifics literature. Finally the traditional ecological knowledge from the fishermen about the fish ecology in the Big Lake must be used as a subsidy study of lakes management, establishing in this way, an information resource for scientific works at the same time to minimize the cost with a long research.
\end{abstract}

Keywords: ethno-ichthyology, fish ecology, fishermen, Amazon, flood lakes.

REBELO, S.R.M., FREITAS, C.E.C. \& SOARES, M.G.M. Dieta de peixes do lago Grande de Manacapuru: uma aproximação com o conhecimento tradicional. Biota Neotrop. 10(3): http://www.biotaneotropica.org.br/ v10n3/pt/abstract?article+bn00810032010.

Resumo: No Amazonas a pesca é uma das principais atividades econômicas e de maior valor tradicional para as comunidades ribeirinhas da região. Estas têm conhecimentos sobre a bioecologia dos peixes que exploram, pois praticam a atividade pesqueira diariamente, o que torna esse conhecimento fortalecido ao longo das gerações. $\mathrm{O}$ estudo tem por objetivo verificar se o conhecimento tradicional dos pescadores ribeirinhos, sobre a dieta alimentar de tambaqui, tucunaré, pacu, acará-açú, curimatã, aruanã, matrinxã, piranha e pirapitinga, é similar com aquele levantado em laboratório. Para tal, foram realizados em comunidades dos lagos Jaitêua e São Lourenço no complexo Lago Grande de Manacapuru, no período agosto de 2006 a outubro de 2008, questionários sobre os alimentos dos peixes, aplicados a 62 pescadores. O estudo aponta um detalhado conhecimento dos pescadores acerca da alimentação dos 9 tipos de peixes que são similares, no período de cheia, com os resultados obtidos em laboratório e em pesquisas literárias durante esta investigação. O estudo conclui que o conhecimento dos pescadores do Lago Grande é de fundamental importância para o entendimento da biologia pesqueira e podem ser usados como subsídios para políticas de manejo da pesca em lagos de várzeas quando agregados ao conhecimento científico.

Palavras-chaves: etnoictiologia, ecologia de peixes, pescadores, Amazônia, lagos de várzea. 


\section{Introduction}

Fisheries in the Amazonian is a traditional activity with large importance to the economy besides fundamental in the human occupations process in that region, came to be very relevant to the regional people social-economics structure, mainly to the riverine communities (Diegues 1999). These communities are in general composed by the indigenous or migrates people and theirs descendent that divide the work time between agriculture and artesian fisheries. The small communities situated along the riverside and lakes in the Amazon region practice the subsistence fisheries. But eventually the exceed fish are commercialized especially during the low water period.

The riverine dependence in relation to the fish, happens a long time, probably its can be the main factors to determine the fishermen high knowledge level about the regional fish. Once the riverine have cultures that maintain a strong relation with the natural resources. Figure out to systematized this knowledge and permits its use to elaborates sustainable publics politics, detach the applications of ethno-ichthyologic procedure that try learn about the interactions between fishermen and fish under the diverse aspects, including the fisheries tactics, diet and fish names attributions (ethno-taxonomy) (Begossi et al. 2002).

The traditional knowledge also permits the quickly access to the information that will be used in the scientific research related with fish resource conservations and management (Begossi 1999, Garcez \& Sánchez-Botero 2006). Besides, it does involve questions about territory and bringing dada that propitiates answers to the questions about riverine local defense (Pereira 1999). Silvano and Jorgensen
(2008) affirm that this kind of knowledge increases the cultural values, asserting more riverine and fishermen participation in the decision maker process about the fish resource use.

At the Amazon some studies about fish traditional knowledge or ichthyology, still insipidity. Nevertheless, in the floodplain lakes at the Central Amazon some research produced the consistent knowledge about fish ecology and behavioral aspects (Batistella et al. 2005), fish ecological and behavioral aspects (Lima 2003); taxon classification (Begossi \& Garavello 1990); migration, feeding, morphologic variation and informal ordination measure of fishery for large catfish (Barros \& Ribeiro 2005); fish use ecological analysis, medicinal and taboo (Begossi \& Braga 1992, Begossi 1999) and also about the child participations in the familiar fisheries (Garcez \& SánchezBotero 2006). This study investigates the ecological knowledge from the fishermen at the Manacapuru Big Lake related with fish diet composition comparing the information's obtained from the interviewers and from fish stomach content dada analyses.

\section{Material and Methods}

\section{Study area}

This study was realized in six communities: Santo Antônio, Tradicional, Nossa Senhora do Perpétuo Socorro and Assembléia de Deus, situated at the Jaitêua Lake $\left(03^{\circ} 13^{\prime}\right.$ 901' $\mathrm{S}$ and 60 44' 326" W); and in the communities: Nossa Senhora do Perpétuo Socorro and Aparecida from the São Lourenço Lake ( $03^{\circ} 17^{\prime} 555^{\prime \prime} \mathrm{S}$ and $60^{\circ} 43^{\prime} 759^{\prime \prime} \mathrm{W}$ ). These two lakes belong to the Manacapuru Big Lake Complex at the Solimões River left margin (Figure 1).

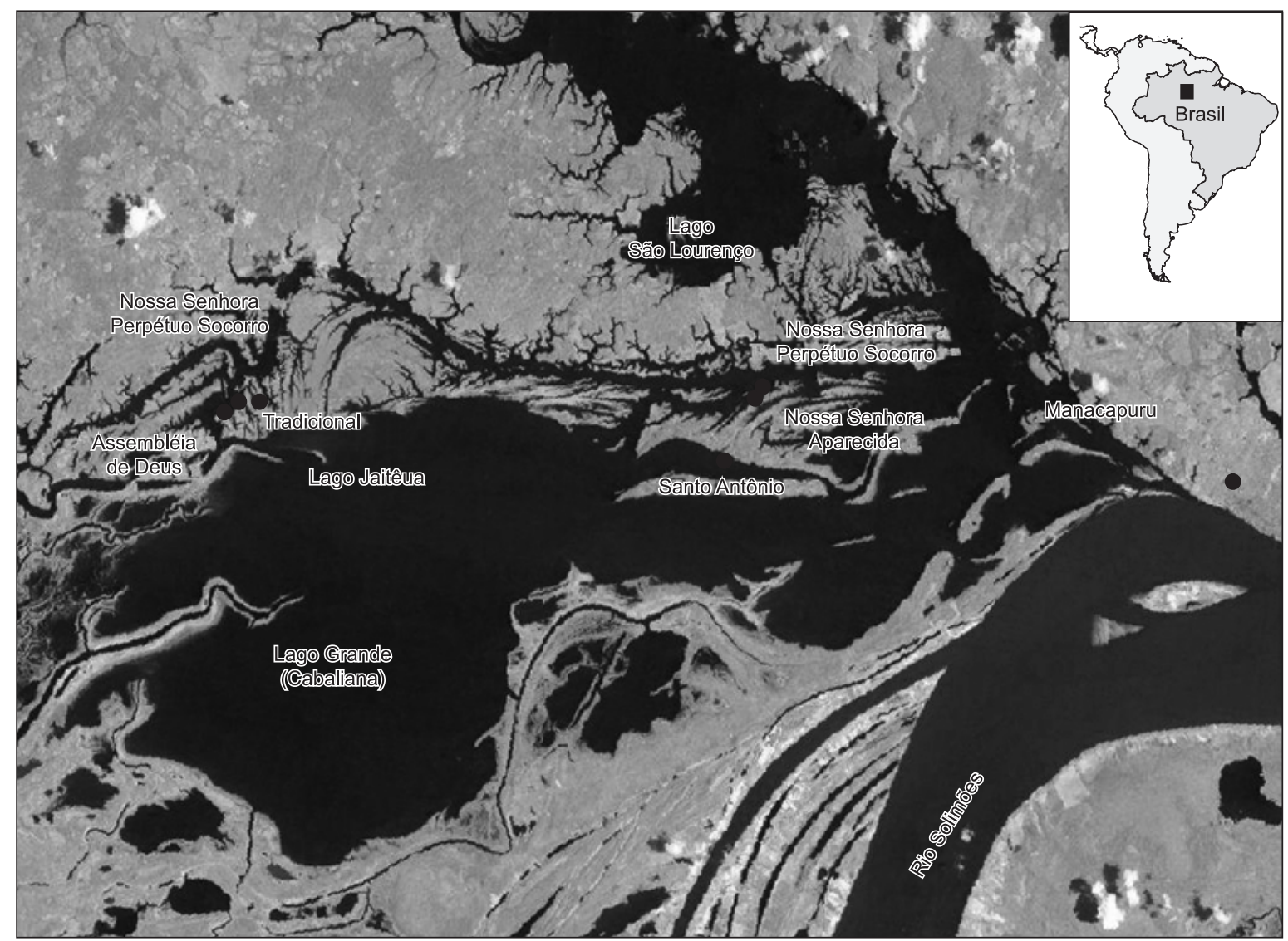

Figure 1. Jaitêua and São Lourenço Lakes localizations, Solimões River, Manacapuru Municipality, Amazon. Resource: BASPA. 


\section{Sample data}

The information about fish diet composition from the most caught fish were collected during the interviews realized by the socioeconomics survey in the (Riverine-caboclos and the fisheries resource ethnoconservation in the Manacapuru) Caboclos-ribeirinhos e a Etnoconservação dos Recursos Pesqueiros em Manacapuru Project, from the Sub-rede BASPA, (Basis for the fishing sustainable in the Amazon).

The questionnaires were applied jointed to 62 fishermen during the period of August 2006 to October 2008, with open and closed questions about the known ichthyofaune feeding. The fish dada used in this research were only one with more than $25 \%$ citation from the fishermen.

Concomitant with the interviews, were realized experimental fisheries in three fishery sectors indicated by the fishermen during the low water level (dry season) November 2006 and during the flood period April 2008. The fish were caught by battery of nets with 20 to $120 \mathrm{~mm}$ between adjacent knots, and the fish were unloaded each six hours in the local fish indicated by the fishermen. The fish species were identified in the field with taxonomical keys and when possible with the fishermen helps (Gery 1977, Santos et al. 1984, Ferreira et al. 1998). After that, the fish stomach were removed, identified by tag and conserved in $10 \%$ of Formaldehyde for posterior analysis in the Floodplain Fish Ecology laboratory at the INPA (Amazon National Research Institute). After, the fish stomachs were washed with current water and fixed in the $70 \%$ alcohol concentration. The fish stomachs were examined sub microscopy stereoscopy and the alimentary item identified until the low taxonomic level. In the stomach content analysis was utilized the occurrence of frequency method (Hyslop 1980, Goulding 1980, Soares et al. 1986).

To make sure if had similarity in the fish diet compositions reported by the fishermen and by the information from the fish stomach content analysis, was applied the No-metric Multidimensional Stagger (NMDS) through the PAST program version 1.78 (Hammer et al. 2008). The NMDS basically consist in summarize in a graphic with perpendicular axles to the multidimensional variation from a group of variable. One similarity matrix was calculated by the Jaccard index, based on presence-absence information from each alimentary item by the every analyzed specie with more then $25 \%(\mathrm{~N} \geq 15)$ known from the interviewers.

\section{Results}

\section{Diet composition}

The fishermen interviewed, $95.2 \%$ known the types of feed eat for the tambaqui (Colossoma macropomum); 69.4\%, tucunaré (Cichla sp.); 41.9\%, pacu (Mylossoma duriventre); 38.71\%, acará-açú (Astronotus crassipinis); 37.1\%, curimatã, (Prochilodus nigricans); $33.87 \%$, aruanã (Osteoglossum bicirrhosum); 30.65\%, matrinxã (Brycon amazonicus); $30.65 \%$, piranha (Pygocentrus nattereri); and $25.81 \%$, pirapitinga (Piaractus brachypomus).

The results for tambaqui, pirapitinga, matrinxã and pacu about the diet composition reported by the fishermen and by the information from the fish stomach content analysis are similar. During the flood and dry periods theses fish species have their diet composed mainly by the vegetable material (fruits, seeds, leaves and flowers) caught from the trees in the floodplain. Meanwhile, the fishermen sited other alimentary item that complement the fish diet as small invertebrates, periphyton and fish for the tambaqui; shrimp and fish for the pirapitinga; gastropod and decapods for the matrinxã; decapods and periphyton for the pacu (Table 1).

For the tucunaré, piranha and aruanã the results about diet fish composition mentioned by the fishermen and from content stomach analysis also were similar. During the flood and dry season, the main alimentary item ate was fish. Others alimentary item consumed by theses fish were decapods (tucunaré), arthropod and vegetal material (piranha and aruanã) (Table 2).

Acará-açú, according to the fishermen answers, this fish eat similar alimentary item during the both periods: gastropod, vegetable material, arthropod, fish and zooplankton. The analysis also showed

Table 1. Frequency of occurrence of the fish alimentary item cited by the interviewers during the Flood (FL) and Drought (DR) season. ( $\mathrm{n}=$ number of interviewers)

\begin{tabular}{|c|c|c|c|c|c|c|c|c|c|c|c|c|c|c|c|c|c|c|}
\hline \multirow[t]{2}{*}{$\begin{array}{l}\text { Alimentary } \\
\text { items }\end{array}$} & \multicolumn{2}{|c|}{$\begin{array}{c}\text { Cichla } \\
\text { monoculus } \\
(\mathrm{n}=43)\end{array}$} & \multicolumn{2}{|c|}{$\begin{array}{c}\text { Colossoma } \\
\text { macropomum } \\
(\mathrm{n}=59) \\
\end{array}$} & \multicolumn{2}{|c|}{$\begin{array}{c}\text { Piaractus } \\
\text { brachypomus } \\
(\mathrm{n}=16)\end{array}$} & \multicolumn{2}{|c|}{$\begin{array}{c}\text { Pygocentrus } \\
\text { nattereri } \\
(\mathrm{n}=19) \\
\end{array}$} & \multicolumn{2}{|c|}{$\begin{array}{c}\text { Mylossoma } \\
\text { duriventre } \\
(\mathrm{n}=26)\end{array}$} & \multicolumn{2}{|c|}{$\begin{array}{c}\text { Brycon } \\
\text { amazonicus } \\
(\mathrm{n}=19) \\
\end{array}$} & \multicolumn{2}{|c|}{$\begin{array}{c}\text { Prochilodus } \\
\text { nigricans } \\
(\mathrm{n}=23) \\
\end{array}$} & \multicolumn{2}{|c|}{$\begin{array}{c}\text { Osteoglossum } \\
\text { bicirrhosum } \\
(\mathrm{n}=21)\end{array}$} & \multicolumn{2}{|c|}{$\begin{array}{c}\text { Astronotus } \\
\text { crassipinis } \\
(\mathrm{n}=24)\end{array}$} \\
\hline & FL & DR & FL & DR & FL & DR & FL & DR & FL & DR & FL & DR & FL & DR & FL & DR & FL & DR \\
\hline $\begin{array}{l}\text { Gastropoda } \\
\text { (snails) }\end{array}$ & 4,7 & 4,7 & - & 5,3 & - & - & - & - & - & - & - & 5 & - & - & 4,8 & - & 50 & 25 \\
\hline $\begin{array}{l}\text { Decapoda } \\
\text { (shrimp) }\end{array}$ & 60,5 & 39,5 & - & - & 6,3 & 18,8 & 20 & - & 11,5 & 7,7 & - & 5,3 & - & 4,2 & 9,5 & 4,8 & - & - \\
\hline $\begin{array}{l}\text { Plant material } \\
\text { (fruits, flowers, } \\
\text { leaves and } \\
\text { seeds) }\end{array}$ & 16,3 & 7 & 68,4 & 31,6 & 62,5 & 12,5 & - & - & 69,2 & 30,8 & 55 & 5 & 8,3 & 33,3 & 4,8 & - & 20,8 & 12,5 \\
\hline $\begin{array}{l}\text { Arthropoda } \\
\text { (spiders and } \\
\text { insects) }\end{array}$ & - & - & - & - & - & - & - & 5 & 3,8 & - & - & - & - & - & 23,8 & 23,8 & 25 & 12,6 \\
\hline $\begin{array}{l}\text { Detritus } \\
\text { (mud / land) }\end{array}$ & - & - & - & - & - & - & - & - & - & - & - & - & 4,2 & 8,3 & - & - & - & - \\
\hline $\begin{array}{l}\text { Periphyton } \\
\text { (slime) }\end{array}$ & 2,3 & - & - & 10,5 & - & - & 5 & - & 3,8 & 3,8 & - & - & 58,3 & - & - & - & - & - \\
\hline Fishes & 69,8 & 65,1 & 5,3 & 5,3 & 6,3 & 12,5 & 80 & 55 & - & 3,8 & 5,0 & - & - & - & 52,4 & 33,3 & 25 & 8,3 \\
\hline Zooplankton & 2,3 & - & - & 5,3 & - & - & 10 & 5 & - & - & - & - & - & - & - & - & - & - \\
\hline $\begin{array}{l}\text { Small } \\
\text { vertebrates } \\
\text { (lizard, snake, } \\
\text { bat, rat, frog) }\end{array}$ & - & 2,3 & 5,3 & 21,1 & - & - & - & - & - & - & - & - & - & - & 28,6 & 19 & 29,2 & 12,5 \\
\hline
\end{tabular}


Table 2. Frequency of occurrence of the fish alimentary item identified in the stomach content during the flood $(\mathrm{CH})$ and drought $(\mathrm{SC})$ season. $(\mathrm{n}=\mathrm{number}$ of stomachs analyzed).

\begin{tabular}{|c|c|c|c|c|c|c|c|c|c|c|c|c|c|c|c|c|c|c|}
\hline \multirow[t]{2}{*}{$\begin{array}{l}\text { Alimentary } \\
\text { items }\end{array}$} & \multicolumn{2}{|c|}{$\begin{array}{c}\text { Cichla } \\
\text { monoculus } \\
(n=43)\end{array}$} & \multicolumn{2}{|c|}{$\begin{array}{c}\text { Colossoma } \\
\text { macropomum } \\
(\mathbf{n}=59)\end{array}$} & \multicolumn{2}{|c|}{$\begin{array}{c}\text { Piaractus } \\
\text { brachypomus } \\
(\mathbf{n}=16) \\
\end{array}$} & \multicolumn{2}{|c|}{$\begin{array}{c}\text { Pygocentrus } \\
\text { nattereri } \\
(\mathbf{n}=19)\end{array}$} & \multicolumn{2}{|c|}{$\begin{array}{c}\text { Mylossoma } \\
\text { duriventre } \\
(\mathbf{n}=\mathbf{2 6})\end{array}$} & \multicolumn{2}{|c|}{$\begin{array}{c}\text { Brycon } \\
\text { amazonicus } \\
(\mathbf{n}=19)\end{array}$} & \multicolumn{2}{|c|}{$\begin{array}{c}\text { Prochilodus } \\
\text { nigricans } \\
(\mathbf{n}=\mathbf{2 3})\end{array}$} & \multicolumn{2}{|c|}{$\begin{array}{c}\text { Osteoglossum } \\
\text { bicirrhosum } \\
(\mathbf{n}=\mathbf{2 1})\end{array}$} & \multicolumn{2}{|c|}{$\begin{array}{c}\text { Astronotus } \\
\text { crassipinis } \\
(\mathbf{n}=\mathbf{2 4})\end{array}$} \\
\hline & FL & DR & FL & DR & FL & DR & FL & DR & FL & DR & FL & DR & FL & DR & FL & DR & FL & DR \\
\hline $\begin{array}{l}\text { Gastropoda } \\
\text { (snails) }\end{array}$ & - & - & - & - & - & - & - & - & - & - & - & - & - & - & - & - & - & - \\
\hline $\begin{array}{l}\text { Decapoda } \\
\text { (shrimp) }\end{array}$ & - & - & - & 57,1 & - & 50,0 & 16,7 & 2,1 & - & - & - & - & - & - & - & - & 50,0 & - \\
\hline $\begin{array}{l}\text { Plant material } \\
\text { (fruits, flowers, } \\
\text { leaves and seeds) }\end{array}$ & - & - & 94,7 & 61,9 & 100,0 & 100,0 & 8,3 & 52,2 & 100,0 & 87,5 & 93,3 & 100,0 & - & 20,0 & 50,0 & - & 37,5 & - \\
\hline $\begin{array}{l}\text { Arthropoda } \\
\text { (spiders and } \\
\text { insects) }\end{array}$ & - & - & 5,3 & 9,5 & 66,7 & 100,0 & 75,0 & 18,8 & - & - & 66,7 & - & - & 20,0 & 50,0 & - & 37,5 & - \\
\hline $\begin{array}{l}\text { Detritus } \\
\text { (mud / land) }\end{array}$ & - & - & 2,6 & - & - & - & 8,3 & 4,3 & 7,7 & 37,5 & - & - & - & 60,0 & - & - & - & - \\
\hline $\begin{array}{l}\text { Periphyton } \\
\text { (slime) }\end{array}$ & - & - & - & - & - & - & - & - & - & - & - & - & - & - & - & - & - & - \\
\hline Fishes & 100,0 & 100,0 & 2,6 & 9,5 & - & 100,0 & 75,0 & 62,5 & 7,7 & 12,5 & - & - & - & 40,0 & 50,0 & - & 50,0 & - \\
\hline Zooplankton & - & - & - & - & - & - & 33,3 & - & - & 12,5 & - & - & - & - & 50,0 & - & - & - \\
\hline $\begin{array}{l}\text { Small vertebrates } \\
\text { (lizard, snake, } \\
\text { bat, rat, frog) }\end{array}$ & - & - & - & - & - & - & - & - & - & - & - & - & - & - & - & - & - & - \\
\hline
\end{tabular}

that this fish consumed vegetable material and arthropod adding fish and shrimp.

Curimatã, according to the fishermen during the flood period consume periphyton, vegetable material, and during the dry season this fish eats detritus. The stomach content analysis point to high frequency of detritus with $(60 \%)$ followed by particles of fish, vegetable material and arthropod.

In the flood period the NMDS analysis shows two groups (Figure 2). In the group A there are the fish piranha (piranE), tucunaré (tucE), aruanã (aruE) and acará-açú (açúE) whose alimentary item as fish and decapods, that were mentioned by the fishermen with more occurrence of frequencies (Figure 2).

In the group B there are the acará-açú (açúC), matrinxã (matC); tambaqui (tambC), pirapitinga (pirapC), piranha (piranC), aruanã $(\operatorname{aruC})$ and pacu (pacC) whose the alimentary item, vegetal matter and fish, were identified with more occurrence of frequencies in the stomach content analysis. More to the central position, piranha (piranC), pacu (pacC), tambaqui (tambC), matrinxã (matC), aruanã (aruC) and acará-açú (açúC) are a indicative that the fish consumed more alimentary item than reported from the fishermen (Figure 2). The other fish separated from another's during the high water level, due to its higher alimentary specificity feeding just in one alimentary item, as the fish curimatã (curC, curE) and tucunaré (tucC); and in two items, the fish pacu (pacE), tambaqui (tambE), pirapitinga (pirapE) and matrinxã (matE).

In other hand, during the drought the NMDS analysis indicates the fish dispersion in relation to the alimentary item consumed, did not occurring the similarity that permits the formation of groups. In this period is higher the omnivore behavior (Figure 3 ).

The results from the NMDS for the two seasons, flood and drought, present one tendency for the fishermen in considering the tambaqui (tambE), piranha (piraE), matrinxã (matE) and pacu (pacE) specialists, seen that mentions just one dominant feed in the diet. Different from that one identified in the stomach content analysis in these fish that pointed two and three alimentary items.

\section{Discussion}

The fishermen knowledge from the fish diet composition perception is wide. Seen this acquired knowledge got from the fishermen practice and from the generations occurs in the moment when the fish is prepared to consumption or commercialization.

The fishermen richness information about fish alimentary behavior in the Manacapuru Big Lake is wide, once they describe the alimentary items more consumed from the fish, yonder them points that one to replace the main alimentary item when it is scarce. When compared the fish diet composition information from the fishermen about fish stomach content analysis, the information were similar with other identified in the laboratory in relations with main alimentary item. Meanwhile when were include all fish diet composition the results were different.

The fishermen point of view according to the fish stomach analysis realized in the laboratory, the tucunare and piranha are piscivore; tambaqui, pirapitinga, matrinxã and pacu are omnivores, tendency to be herbivore; curimatá is detritivorous; aruanã and acará-açú are omnivore with a tendency to be a carnivore.

Tambaqui, pirapitinga, matrinxã and pacu, eats various types of fruits and seeds during the flood period in the floodplain area. When the water retraction limits the food offer during the dry season, these fish complements or substitutes its kind of food for other, as a small arthropods and decapods. For the acará-açú there are not similarity between the fishermen knowledge and the analysis of stomach contents. But, the presence of aruá (gastropod) in the diet in agreement with fishermen reported are in according to information reported by the alimentary fish studies (Ferreira 1998, Winemiller 1990).

Also, was compared the information from the fishermen about tucunaré, piranha, tambaqui, pirapitinga, matrinxã, pacu and curimatã with these reported by the alimentary studies research realized in the floodplain lakes at the Amazonian, have noted similarity in the diet composition. Tucunaré is a fish food voracious consumer, but shrimp also belong to its diet composition (Mérona et al. 2001, Mérona \& 


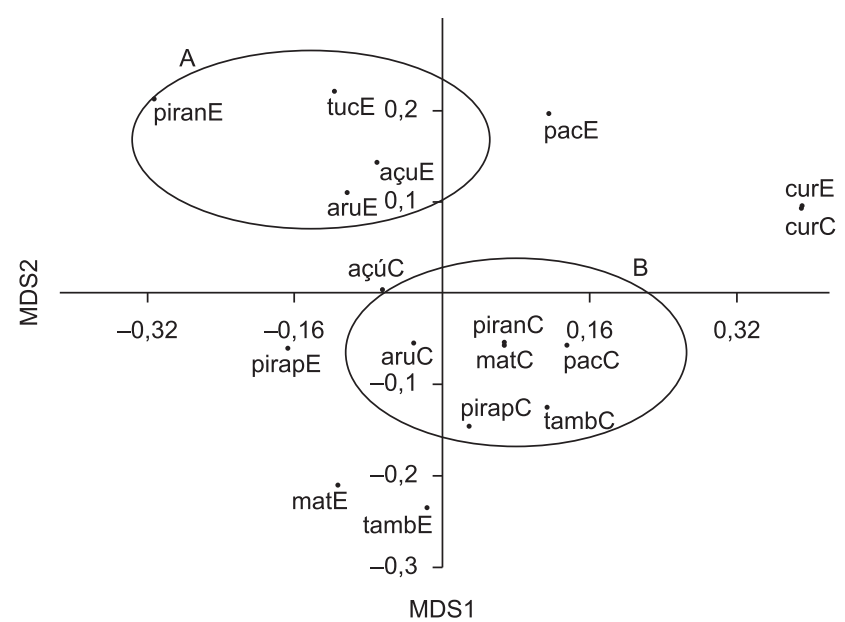

Figure 2. Similarity between Scientific Knowledge (tucunaré $=$ tucC; tambaqui $=$ tambC; pirapitinga $=$ pirapC; piranha $=$ piraC; pacu $=$ pacC matrinxã = matC; curimatã $=$ curC; aruanã $=$ aruC; acará-açú $=$ açúC) and traditional knowledge of the fishermen (tucunare $=$ tucE; tambaqui $=$ tambE; pirapitinga $=$ pirapE; piranha $=$ piraE; pacu $=$ pacE; matrinxã $=$ matE; curimatã $=$ curE; aruanã $=$ aruE; acará-açú $=$ acuE) about the diet composition for the Icthiofauna in the Flood season.

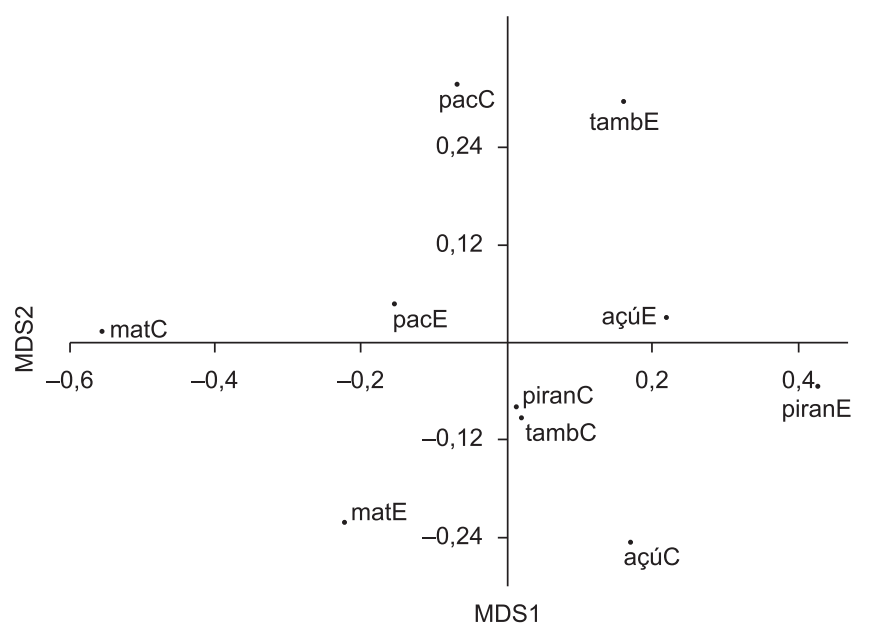

Figure 3. Similarity between Scientific Knowledge (tucunaré = tucC; tambaqui $=$ tambC $;$ pirapitinga $=$ pirapC $;$ piranha $=$ piraC $;$ pacu $=$ pacC; matrinxã = matC; curimatã $=$ curC; aruanã $=$ aruC; acará-açú $=$ açúC) and traditional knowledge of the fishermen (tucunare $=$ tucE; tambaqui $=$ tambE; pirapitinga $=$ pirapE; piranha $=$ piraE; pacu $=$ pacE; matrinxã $=$ matE; curimatã = curE; aruanã = aruE; acará-açú = açúE) about the diet composition of Similarity between Scientific Knowledge during the drought season.

Rankin-de-Mérona 2004), piranha has alimentary spectrum amplified, because its eat yonder fish also terrestrial arthropod occasionally, crustacean and vegetable material (Goulding 1980, Pouilly et al. 2003, Mérona \& Ranking-de-Mérona 2004), tambaqui and pacu consuming mainly fruits and seeds, leaves from the floodplain forest (Goulding 1980, Silva 1997, Mérona \& Ranking-de-Mérona 2004); pirapitinga and matrinxã, yonder fruits and seeds also eats terrestrial and aquatic invertebrates (Goulding 1980, Mérona \& Ranking-de-Mérona 2004); curimatã is detritivorous, feeds with detritus adding with microfaune, organic amorphous material or litter associated with sedimentary material (Araújo-Lima et al. 1986, Mérona \& Ranking-de-Mérona 2004). For the aruanã diet composition was different from the cited in the literature that lists the terrestrial invertebrates (insects) as the more important alimentary item (Mérona \& Ranking-de-Mérona 2004, Chaves et al. 2006).

There is no similarity between the fishermen and the scientific information in relation to the acará-açú and aruanã diet. Its happened due the fishermen knowledge are obtained from the information accumulated through conversations and mainly from the temporal environmental perception acquired in the lived place. In other hand, the identification of alimentary item from the stomach content analysis is punctual, once the analyzed material was sampled from the one determined sample site and during specific time. In this way, to compare the information between the fishermen traditional knowledge and the scientific knowledge not means that one or other can be wrong, once the temporal/spatial vision about the environment are different for the both.

This research concludes that the fishermen interviewed in the Manacapuru Big Lake known very well the fish diet and its variations for the species that their caught, corroborating with the laboratory analysis realized in this research, with similarities information from the studied fish species as tucunaré, tambaqui, pirapitinga, piranha, pacu, matrinxã, curimatã, aruanã and acará-açú. These data can be used as subsidy for fisheries management policy in the floodplain lakes.

\section{Acknowledgements}

We thanks the financial support received from the MCT/ CNPQ/PPG7, FINEP/CTPetro, PIATAM Project; to CAPES for the scholarship conceded; to the fishermen from the Big Lake Complex, with their estimable experience that without its this study does not existing.

\section{References}

ARAÚJO-LIMA, C.A.R.M., FORSBERG, B.R., VICTORIA, R. \& MARTINELLI, L. 1986. Energy source for detritivorous fishes in the Amazon. Science 234:1256-1258.

BARROS, J.F. \& RIBEIRO, M.O.A. Aspectos sociais e conhecimento ecológico tradicional na pesca. In $\mathrm{O}$ manejo da pesca dos grandes bagres migradores piramutaba e dourada no eixo Solimões-Amazonas (R.B. Barthem \& N. Fabré, coords.). ProVarzea, Manaus, 2005.

BATISTELLA, A.M., CASTRO, C.P. \& VALE, J.D. 2005. Conhecimento dos moradores da comunidade de Boas Novas, no Lago Janauacá Amazonas, sobre os hábitos alimentares dos peixes da região. Acta Amazon. 1(35):51-54.

BEGOSSI, A. \& BRAGA, F.M.S. 1992. Food taboos and folk medicine from the Tocantins river (Brazil). Amazoniana 12:101-118.

BEGOSSI, A. \& GARAVELLO, J.C. 1990. Notes on the ethnoicthyology of fisher-men from the Tocantis River (Brazil). Acta Amazon. 20:341-352.

BEGOSSI, A. 1999. Caiçaras, Caboclos and Natural Resources: Rules and Scale Patterns. Ambient. Soc. 2(5):55-67.

BEGOSSI, A., HANAZAKI, N. \& SILVANO, A.M. 2002. Ecologia Humana, Etnoecologia e Conservação. In Métodos de Coleta e Análise de Dados em Etnobiologia, Etnoecologia e Disciplinas Correlatas (M.C.M. Amorozo, L.C. Ming \& S.P. Silva, eds.). UNESP; SBEE; CNPq, Rio Claro, 204p.

CHAVES, R., CAMARGO, M., QUEIROZ, H. \& HERCOS, A. 2005. Ritmo de atividade diária de Osteoglossum bicirrhosum (PEIXES: OSTEOGLOSSIFORMES) em quatro lagos da Reserva de Desenvolvimento Sustentável de Mamirauá (AM). UAKARI 1(1).

DIEGUES, A.C. 2000. Etnoconservação da natureza: enfoques alternativos. In Etnoconservação: novos rumos para a proteção da natureza nos trópicos (A.C. Diegues, ed). 2 ed. Hucitec Ltda., São Paulo, p. 01-46.

FERREIRA, E.J.G., ZUANON, J.A.S. \& SANTOS, G.M. 1998. Peixes comerciais do médio Amazonas: Região de Santarém - PA. IBAMA, Brasília, DF, 211p. Série Estudos: Pesca. Coleção Meio Ambiente. 
GARCEZ, D.S \& SÁNCHEZ-BOTERO, J.I. 2006. La pesca practicada por niños ribereños de Manacapuru, Amazônia Central, Brasil. Bol. Inst. Pesca 1(32):79-85.

GERY, J. 1977. Characoids of the wold. T.F.H. Publications, Inc. Neptune, USA, 672p.

GOULDING, M. 1980. The fishes and the forest. Explorations in Amazonian natural history. University of California Press, Berkeley, 280p.

HAMMER, Ø., HARPER, D.A.T. \& RYAN, P.D. 2008. PaST-Palaeontological Statistcs, Version 1.78. http://folk.uio.no.ohammer/past (último acesso em: 10/01/2008).

HYSLOP, E.J. 1980. Stomach contents analysis review of methods and their applications. J. Fish Biol. 17:411-429.

LIMA, L.G. 2003. Aspectos do Conhecimento Etnoictiológico de Pescadores Citadinos Profissionais e Ribeirinhos na Pesca Comercial de Amazônia Central. Dissertação de Mestrado, UFAM, Manaus, 116p.

MÉRONA, B. \& RANKIN-DE-MERONA, J. 2004. Food resource partitioning in a fish community of the central Amazon floodplain. Neotrop. Ichthyol. 2(2):75-84.

MÉRONA, B., SANTOS, G.M. \& ALMEIDA, R.G. 2001. Short term effects of Tucuruí Dam (Amazonia, Brazil) on the trophic organization of fish communities. Environ. Biol. Fisches 60:375-392.
PEREIRA, H.S. 1999. Common-property regimes in Amazonian fisheries. Tese de Doutorado, The Graduate School Intercollege Graduate Degree Program in Ecology, The Pennsylvania State University, 119p.

POUILLY, M., LINO, F., BRETENOUX, J.-G. \& ROSALES, C. 2003. Dietary- morphological relationships in a fish assemblage of the bolivian amazonian floodplain. J. Fish Biol. 62:1137-1158.

SANTOS, G.M., JÉGU, M. \& MÉRONA, B. 1984. Catálogo de peixes comerciais do baixo rio Tocantins. Projeto Tucuruí. ELETRONORTE; CNPq; INPA, Manaus, 83p.

SILVANO, R.A.M. \& JORGENSEN, J.V. 2008. Beyond fishermen's tales: contribution of fishers' local ecological knowledge to fish ecology and fisheries management. Environ. Dev. Sustain. 10:657-675.

SOARES, M.G.M., ALMEIDA, R.G. \& JUNK, W.J. 1986. The trophic status of the fish fauna in Lago Camaleão, a macrophyte dominated floodplain lake in the middle Amazon. Amazoniana 9(4):511-526.

WINEMILLER, K. O. 1990 Caudal eye spots as deterrents against fin predation in the neotropical cichlid Astronotus ocellatus. Copeia, Lawrence, v. 3, p. 665-673.

Received 30/11/2009

Revised 21/05/2010

Accepted 03/07/2010 